\title{
Phytochemicals, antioxidant, antinociceptive and anti-inflammatory potential of the aqueous extract of Teucrium stocksianum bioss
}

Syed Muhammad Mukarram Shah ${ }^{1 *}$ and Syed Muhammad Hassan Shah ${ }^{2}$

\begin{abstract}
Background: Despite availability of a substantial number of potent synthetic drugs, medicinal plants are still playing a key role in the discovery of novel and effective drug molecules. Numerous researchers are focusing on the plant based medicines due to its strong safety profiles. Teucrium species exhibit profound antidiabetic, analgesic and spasmolytic activities. The methanolic extract and essential oil of Teucrium stocksianum possess strong antinociceptive activity. The aim of the current research study was to determine the phytochemicals, antioxidant, analgesic and anti-inflammatory potential of the aqueous extract of Teucrium stocksianum Bioss (AETS).
\end{abstract}

Method: Phytochemical screening was carried out according to standard procedures. The antioxidant potential of the extract was ascertained with the stable organic free radical (2, 2-diphenyl-1-picryl-hydrazyl). Three different pain models, including acetic acid induced writhing, formalin induced paw licking and tail immersion tests were carried out for the determination of antinociceptive potential, while the anti-inflammatory activity was evaluated through carrageenan induced paw edema test in mice. The antinociceptive and anti-inflammatory potentials of AETS were assessed at 100, 200 and $300 \mathrm{mg} / \mathrm{kg}$ body weight, while acute toxicity were observed at $1500 \mathrm{mg} / \mathrm{kg}$ body weight in various groups of mice.

Results: Phytochemical screening has shown the occurrence of flavonoids saponins, reducing sugars, terpenoids and tannins. AETS exhibited profound antioxidant activity and has shown maximum activity (60.06 \pm 0.846$)$ at $250 \mathrm{\mu g} / \mathrm{ml}$. In the three pain models AETS displayed marked dose dependent antinociceptive potential. AETS exhibited 63.5, 67.61 and $64 \%$ activity in acetic acid induced, formalin induced paw licking and tail immersion tests respectively. The antinociceptive effect of AETS and reference standard drug Tramadol ${ }^{R}$ was significantly reversed by Naloxone, endorsed the central analgesic potential of AETS. Similarly the extract also reversed the paw edema in dose dependent manner. AETS displayed significant (53.81\%) anti-inflammatory effects at a dose of $300 \mathrm{mg} / \mathrm{kg}$ that persisted till $5^{\text {th }} \mathrm{h}$. In acute toxicity test AETS was found safe at $1500 \mathrm{mg} / \mathrm{kg}$ body weight.

Conclusions: AETS exhibited profound antioxidant activity. The test sample displayed marked antinociceptive potential in all the test procedures, indicating the peripheral and central analgesic effects of AETS. The plant extract also displayed marked anti-inflammatory activity at all test doses.

Keywords: Teucrium stocksianum, Phytochemicals, Antioxidant, Antinociceptive, Anti-inflammatory

\footnotetext{
* Correspondence: shahpharmacist@yahoo.com

${ }^{1}$ Department of Pharmacy, University of Malakand, Chakdara Dir, KPK,

Pakistan

Full list of author information is available at the end of the article
}

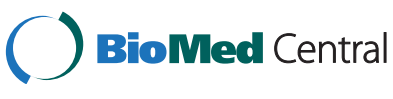

(c) 2015 Shah and Shah. Open Access This article is distributed under the terms of the Creative Commons Attribution 4.0 International License (http://creativecommons.org/licenses/by/4.0/), which permits unrestricted use, distribution, and reproduction in any medium, provided you give appropriate credit to the original author(s) and the source, provide a link to the Creative Commons license, and indicate if changes were made. The Creative Commons Public Domain Dedication waiver (http://creativecommons.org/publicdomain/zero/1.0/) applies to the data made available in this article, unless otherwise stated. 


\section{Background}

The family Lamiaceae comprises of 220 genera and 4000 species around the world. They are most frequently used in indigenous medicines throughout the globe. Various plants of this genera have been used traditionally for the treatment of various ailments, i.e., Teucrium polium Linn is used ethno-medicinally for the treatment of pain associated with pregnancy, flatulence, analgesia, liver disorders, jaundice, coughing and miscarriage [1-4].

A number of compounds have been isolated from different species of Teucrium. Montanins A, B, C, D and E were isolated from Teucrium montanum [5, 6]. Teucrins A and E have been obtained from Teucrium chamaedrys [7]. Compounds isolated from Teucrium quadrifarium include, 12-epi-teucvidin, teucvidin, teuflin, teucvidin, 19-acetyl-teuspinin and teuquadrin B were isolated [8]. Coll et al. [9], have isolated neo-clerodanes, namely 6acetyl-10-hydroxyteucjaponin B, 11-hydroxyfruticolone, 6-acetylteucjaponin B, 7- $\beta$-hydroxyfruticolone and deacetylfruticolone from Teucrium fruticans.

There have been reported various biological activities from Teucrium species, like antioxidant [10], antiseizure [11], hepatoprotective, antimicrobial, butarylcholine and acetylcholine esterase inhibition activities [12, 13]. Teucrium stocksianum is one of the important members of the genus Teucrium. The methanolic extract and its subsequent fractions have exhibited strong insecticidal, cytotoxic and phytotoxic potentials $[14,15]$. The aqueous extracts are most frequently used in the traditional medicine system for the treatment of various disease conditions. Thus in ordered to evaluate and authenticate the folkloric analgesic effect of the plant we therefore determined the antioxidant, antinociceptive and antiinflammatory potential of the AETS. Furthermore the current study is the extension of our previous research project in which we have determined the antioxidant and antinociceptive potential of the essential oil and methanolic extracts of the same plant $[16,17]$.

\section{Methods}

Plant material

Teucrium stocksianum was collected in the month of May 2014 from District Swat (Marghuzar valley) in the province of Khyber Pakhtunkhwa (KPK), Pakistan. The plant was authenticated by Professor Dr. Nisar, Department of Botany University of Malakand, KPK, Pakistan. Plant specimen (voucher No, H.UOM.BG.199) was deposited in University Herbarium for future reference.

\section{Preparation of plant extract}

The whole plant was air dried under shade, cut into small pieces and pulverized to coarse powder. About $100 \mathrm{~g}$ of the powdered plant material was stirred with $500 \mathrm{ml}$ distilled water at $95{ }^{\circ} \mathrm{C}$ for $25 \mathrm{~min}$. The aqueous extract of T. stocksianum (AETS) was filtered through Whatman's \#1 filter paper. The AETS was concentrated on water bath at $45{ }^{\circ} \mathrm{C}$. The concentrated extract was stored in glass container in refrigerator for future use.

\section{Experimental animal}

Male and female, Swiss albino mice of same age having 20-30 g weight, were procured from National Institute of Health, Islamabad Pakistan. All the animals were kept in appropriate cages at standard controlled laboratory condition $\left(23{ }^{\circ} \mathrm{C}, 12 \mathrm{~h}\right.$ light and $12 \mathrm{~h}$ dark cycle). Food and water were given to all the experimental animals ad libitum during acclimatization period. The food was withheld $18 \mathrm{~h}$ prior to experiment from all animals while water was available during this period. The animals were randomly divided into various groups $(n=6)$. The experimental protocol for animal studies was approved by the legal bodies (Ethical committee) of University of Malakand KPK, Pakistan according to the guidelines of Scientific Procedure Issue-1 of Animal bylaws 2008.

\section{Chemicals and drugs}

Tramadol $^{\mathrm{R}}$ manufactured by Searle Pakistan Ltd (Trade name Tramal) was procured from local market, Naloxone was purchased from Acent Scientific Company, Diclofenic sodium obtained from Sigma and Aspirin manufactured by Reckitt \& Colman was used.

\section{Statistics and calculations}

The data obtained were expressed as mean \pm Standard error of mean (SEM) and Standard deviation (S.D) of six animals. One-way analysis of variance (ANOVA) and post hoc Dunnett's test was applied for the comparison among different groups. Differences with $P \leq 0.05$ and lower between groups were considered significant.

\section{Acute toxicity}

For the determination of possible toxicity of the aqueous extract, acute toxicity test was performed. Animals were divided into four groups of either sex $(n=6)$ and were treated with 500, 1000 and $1500 \mathrm{mg} / \mathrm{kg}$, i.p. The control group received Normal saline $(10 \mathrm{ml} / \mathrm{kg})$. All the animals were continuously observed for any gross effect during first $4 \mathrm{~h}$ and then the number of dead animals were counted after $24 \mathrm{~h}$ [18].

\section{Antioxidant potential}

\section{DPPH (2, 2-diphenyl-1-picryl-hydrazyl) radical scavenging} potential

DPPH is a stable organic free radical, mostly used for the determination of radical scavenging potential of extract of phytomedicines. The activity was carried out according to the protocol described by Chou et al. [19] with slight modifications. Methanolic solution of DPPH 
(1 $\mathrm{mM})$ was prepared and $01 \mathrm{ml}$ of this solution was mixed to the calculated volume of the aqueous solution of sample containing 20,40,60, 80 and $100 \mu \mathrm{g}$ of the extract respectively. All the test samples, reference standard and control solutions were incubated for half an hour, at controlled temperature $\left(20-25{ }^{\circ} \mathrm{C}\right)$ in the complete absence of light. Afterwards, samples, control and standard were analyzed at $517 \mathrm{~nm}$ and absorbance was recorded. DPPH radical scavenging effect was calculated as the inhibition percentage and was determined by the following equation.

$$
\% \text { RSA }=\frac{\text { Control absorbance }- \text { Sample absorbance }}{\text { Control absorbance }} \times 100
$$

The test for each sample was carried out in triplicate and the results were expressed as mean $\pm \mathrm{SD}$. Inhibitory concentration $\left(\mathrm{IC}_{50}\right)$ was determined from the graph of $\%$ RSA. Quercetin and Ascorbic acid were used as reference standards.

\section{Analgesic potential \\ Acetic acid induced abdominal writhing test}

Animals were divided into five groups, each containing 06 mice. All the groups received intraperitoneal (i.p) acetic acid solution $(10 \mathrm{ml} / \mathrm{kg}, 0.6 \%$, i.p) $30 \mathrm{~min}$ after dosing with either aqueous extract of Teucrium stocksianum (100, 200 and $300 \mathrm{mg} / \mathrm{kg}$ ) or vehicle (0.9\% saline) or reference standard drug, Aspirin $(100 \mathrm{mg} / \mathrm{kg})$. The number of abdominal writhes (constrictions) were recorded after $5 \mathrm{~min}$ of acetic acid administration for a period of $20 \mathrm{~min}$. Percent inhibition was determined by comparing the results of aqueous extract with the control group [20].

\section{Formalin induced paw licking test}

Animals were acclimatized in the observation chamber, 15 min prior to the experiment. Animals were divided into 05 groups $(n=6)$. Test groups were treated with 100,200 and $300 \mathrm{mg} / \mathrm{kg}$ (i.p) aqueous extract of the plant, control group was treated with Normal Saline solution $(0.9 \%, 10 \mathrm{ml} / \mathrm{kg}$, i.p) while the reference standard group received acetylsalicylic acid $(100 \mathrm{mg} / \mathrm{kg}$, s.c). The animals received sub-plantar injection of $20 \mu \mathrm{l}(01 \%)$ formalin solution into the right hind paw, $30 \mathrm{~min}$ after treatment. Subsequently, the total number of paw licking were observed during initial $0-5 \mathrm{~min}$ (Neurogenic phase) and late $20-30 \mathrm{~min}$ (Inflammatory phase) after formalin injection. The experiment was performed under strict condition of no disturbance that may affect the animal's response.

\section{Tail immersion test}

In this experiment, Swiss albino mice of either sex $(n=6)$ weighing 20-30 g, were divided into seven groups. Group
A treated with Normal Saline $(0.9 \%, 10 \mathrm{ml} / \mathrm{kg}$, b.w, i.p), group $\mathrm{B}, \mathrm{C}$ and $\mathrm{D}$ received intraperitoneal injection of 100, 200 and $300 \mathrm{mg} / \mathrm{kg}$, i.p of AETS respectively. Group "E" was treated with Tramadol ${ }^{\mathrm{R}}(30 \mathrm{mg} / \mathrm{kg})$, served as reference standard drug. Pain was induced in each animal by immersing the tail $(2-5 \mathrm{~cm})$ in a pot of water maintained at $54 \pm 0.5{ }^{\circ} \mathrm{C}$. The reaction time (in seconds, is the time taken by the animal to withdraw the tail from warm water) was recorded after $30 \mathrm{~min}$ of dosing. To avoid the tissue damage, $30 \mathrm{~s}$ cut-off time was maintained at $54 \pm 0.5{ }^{\circ} \mathrm{C}$. To ascertain the opioids receptors involvement in the mechanism of analgesia of AETS, group "F" received $300 \mathrm{mg} / \mathrm{kg}$ AETS, $10 \mathrm{~min}$ after subcutaneous injection of naloxone $(0.5 \mathrm{mg} / \mathrm{kg})$. Similarly group "G" was treated with Tramadol ${ }^{\mathrm{R}}(30 \mathrm{mg} / \mathrm{kg})$. The reaction time was observed at $0,30,60,90$ and $120 \mathrm{~min}$ after drug administration respectively [21].

\section{Anti-inflammatory potential \\ Carrageenan induced paw edema test}

The anti-inflammatory potential of the aqueous extract of $T$. stocksianum was evaluated in mice of either sex $(25-30 \mathrm{~g})$. Mice were divided randomly in five groups $(\mathrm{n}=06)$ [22]. Group "I" served as a negative control, treated with $10 \mathrm{ml} / \mathrm{kg}$ of $0.9 \%$ Normal Saline solution, group "II" received Aspirin $100 \mathrm{mg} / \mathrm{kg}$ (positive control), while group III, IV and V received intraperitoneal injection of aqueous extract of T. stocksianum at a dose of 100,200 and $300 \mathrm{mg} / \mathrm{kg}$, respectively. After $30 \mathrm{~min}$ of dosing, each mouse received sub planter injection of freshly prepared carrageenan suspension $(0.05 \mathrm{ml}$ of $1 \% \mathrm{w} / \mathrm{v}$ ) in the right hind paw. Subsequently the inflammation induced was measured with plethysmometer (LE 7500 plan lab S.L) after carrageenan injection and at $1 \mathrm{~h}$ interval for $5 \mathrm{~h}$. The paw volume of the standard drug and AETS treated animals were compared with the negative control group animals and the percent inhibition of inflammation was calculated at different time intervals, using the following formula;

$$
\text { Percent inhibition }=\mathrm{A}-\mathrm{T} / \mathrm{A} \times 100
$$

where $\mathrm{A}$ is the average inflammation of control and $\mathrm{T}$ is the paw volume of test group [23].

\section{Results and discussions}

Owing to phytochemical constituents synthesized by medicinal plants, the plants are considered a very valuable and rich source to obtain the bioactive molecules. The medicinal value of plants is due to phytochemical constituents, synthesized by medicinal plants. Saponins for instance, exhibit significant antidiabetic, cytotoxic and insecticidal activities $[14,15]$. Phytochemical screening of the aqueous extract of $T$. stocksianum showed the 
Table 1 Phytochemical screening of aqueous extracts of T. stocksianum

\begin{tabular}{|c|c|c|c|c|}
\hline S. No & Phytochemicals & Reagents/chemicals & Observations & Results \\
\hline 1 & Flavonoids & $\mathrm{NaOH}+\mathrm{HCl}$ & Discoloration & + \\
\hline 2 & Saponins & Distilled water & Frothing & + \\
\hline 3 & Reducing sugars & Fehling's solution & Orange red precipitation & + \\
\hline 4 & Phlobutanins & $\mathrm{HCL}$ & Red precipitate not found & - \\
\hline 5 & Terpenoids & $\mathrm{CHCl}_{3}+\mathrm{H}_{2} \mathrm{SO}_{4}$ & Dark green colouration & + \\
\hline 6 & Alkaloids & Dragendorff's & Orange red PPTs was not found & - \\
\hline 7 & Tannins & Ferric chloride & Dark green colouration & + \\
\hline 8 & Anthraquinonnes & $\mathrm{HCl}+\mathrm{CHCl}_{3}+\mathrm{NH}_{3}$ & Rose pink colour & - \\
\hline
\end{tabular}

Key $+=$ Present,$-=$ Absent

presence of flavonoids, saponins, reducing sugars, terpenoids and tannins, while phlobutanins, alkaloids, anthraquinonnes and glycosides were not found (Table 1). In our previous work we determined phytochemicals, total phenolic contents and antinociceptive potential of the methanolic extract of T. stocksianum [17]. A rich literature study is available showing that decoctions/ aqueous preparations are most commonly used for the treatment of different diseases in the traditional medicinal system. In the current study we therefore evaluated the phytochemical composition, antioxidant, antinociceptive and anti-inflammatory potential of the aqueous extracts of T. stocksianum.

Antioxidants play a vital role in the control of reactive oxygen species (ROS), produced during cell metabolism. ROS are implicated in the main pathogenesis of diabetes, rheumatic joint pain, atherosclerosis and hypertension $[24,25]$. In DPPH radical scavenging assay the AETS displayed excellent activity in a concentration dependent manner. The extract showed maximum potential (60.06 \%) at $250 \mu \mathrm{g} / \mathrm{ml}$. IC $\mathrm{IC}_{50}$ value was $136 \mu \mathrm{g} / \mathrm{ml}$, as shown in Table 2. The antioxidant potential is mainly due to the presence of phenolic compounds like flavonoids and flavones [26]. The present study confirmed the presence of flavonoids in AETS and it is well documented that flavonoids exhibit significant antioxidant activities (Table 1). Thus it is concluded that the flavonoids might be responsible for antioxidant potential of AETS.

Table 2 DPPH radical scavenging potential of aqueous extract T. stocksianum (AETS)

\begin{tabular}{|c|c|c|c|c|}
\hline \multirow{2}{*}{$\begin{array}{l}\text { Test solutions } \\
\text { Sample/standard }\end{array}$} & \multicolumn{3}{|c|}{ Concentration $\mu \mathrm{g} / \mathrm{ml}$} & \multirow{2}{*}{$\begin{array}{l}\mathrm{IC}_{50} \\
(\mu \mathrm{g} / \mathrm{ml})\end{array}$} \\
\hline & 62.5 & 125 & 250 & \\
\hline AETS & $34.70 \pm 1.454$ & $48.66 \pm 1.50$ & $60.06 \pm 0.846$ & 136 \\
\hline Quercetin & $94.86 \pm 0.872$ & $95.28 \pm 1.24$ & $96.56 \pm 1.52$ & $<62.5$ \\
\hline Acetic acid & $90.62 \pm 1.856$ & $92.45 \pm 1.07$ & $94.24 \pm 1.33$ & $<62.5$ \\
\hline
\end{tabular}

Values are expressed as means \pm SEM of three replicates
Flavonoids have diversified pharmacological activities. Sannigrahi et al; have reported antinociceptive and anti-inflammatory activities of crude flavonoids extracted from Enhydra fluctuans using different animal models [27]. Acetic acid induced abdominal writhing test is a non specific procedure for the determination of analgesia [28]. Sannigrahi et al. [29], have reported antinociceptive and anti-inflammatory activities of crude flavonoids extracted from Enhydra fluctuans using different animal models. In order to relieve the pain mostly narcotic and nonsteridal antiinflammatory drugs are used. In acetic acid induced abdominal writhing test the test groups treated with 100, 200 and $300 \mathrm{mg} / \mathrm{kg}$ of AETS exhibited profound and dose dependent inhibition of the abdominal writhes. Marked activity (63.5 \%) was recorded at $300 \mathrm{mg} / \mathrm{kg}$, as compared to control group. The reference standard drug acetyl salicylic acid produced greater inhibitory effect as compared to the highest dose of AETS, depicted in Table 3. Looking at the results of our previous works it has been found that the AETS possesses less analgesic potential (60.06\% at $300 \mathrm{mg} / \mathrm{kg}$ ) as compared to the methanolic extract of T. stocksianum $(83.103 \%$ at $150 \mathrm{mg} / \mathrm{kg})$. This pain paradigm releases arachedonic acid and prostaglandins from tissue phospholipids through cyclooxygenase

Table 3 Antinociceptive effect of AETS 100, 200 and 300 mg/kg in acetic acid induced abdominal writhing test

\begin{tabular}{llcl}
\hline Samples & Dose & No of writhes & \% inhibition \\
\hline Normal saline & $10 \mathrm{ml} / \mathrm{kg}$ & $73.16 \pm 1.81$ & - \\
AETS & $100 \mathrm{mg} / \mathrm{kg}$ & $44.33 \pm 1.94$ & $39.40^{*}$ \\
& $200 \mathrm{mg} / \mathrm{kg}$ & $36.16 \pm 1.57$ & $50.57^{* *}$ \\
& $300 \mathrm{mg} / \mathrm{kg}$ & $28.5 \pm 1.56$ & $61.10^{* *}$ \\
Acetylsalicylic acid & $100 \mathrm{mg} / \mathrm{kg}$ & $16.0 \pm 1.96$ & $78.13^{* *}$
\end{tabular}

Percent inhibition was calculated in comparison to control group. The data was analyzed by ANOVA followed by Dunnett's test. The significant values from control were presented with asterisks i.e., ${ }^{*} p \leq 0.05$, ${ }^{* *} p \leq 0.01$ 
Table 4 Effect of AETS 100, 200 and $300 \mathrm{mg} / \mathrm{kg}$ in formalin induced paw licking test

\begin{tabular}{|c|c|c|c|c|c|}
\hline \multirow[t]{2}{*}{ Samples } & \multirow[t]{2}{*}{ Dose } & \multicolumn{2}{|l|}{ Phase I } & \multicolumn{2}{|l|}{ Phase II } \\
\hline & & No of paw licking & $\%$ inhibition & No of paw licking & $\%$ inhibition \\
\hline Normal saline & $10 \mathrm{ml} / \mathrm{kg}$ & $49.83 \pm 2.05$ & - & $41.16 \pm 1.95$ & - \\
\hline \multirow[t]{3}{*}{ AETS } & $100 \mathrm{mg} / \mathrm{kg}$ & $42.66 \pm 1.87$ & $14.38^{\text {n.s }}$ & $29.33 \pm 2.01$ & $28.74^{*}$ \\
\hline & $200 \mathrm{mg} / \mathrm{kg}$ & $36.55 \pm 1.94$ & $26.75^{*}$ & $19.33 \pm 2.23$ & $53.04^{* *}$ \\
\hline & $300 \mathrm{mg} / \mathrm{kg}$ & $33.16 \pm 2.30$ & $33.45^{* *}$ & $13.33 \pm 1.99$ & $67.61^{* *}$ \\
\hline Acetylsalicylic acid & $100 \mathrm{mg} / \mathrm{kg}$ & $43.16 \pm 1.66$ & - & $5.833 \pm 0.94$ & $85.83^{* *}$ \\
\hline
\end{tabular}

Values are expressed as mean \pm SEM. The data was analyzed by ANOVA followed by Dunnett's test; Percent $h$ Inibition was calculated in comparison to the control group. Asterisks shows the significant values $\left({ }^{* *} p \leq 0.01\right.$ and $\left.{ }^{*} p \leq 0.05\right)$ vs. control group $(\mathrm{n}=6)$ and $\mathrm{n} . \mathrm{s}$ shows statistically non significant values

(COX) pathway and are responsible for inflammation and pain $[17,30]$. Those drugs molecules which inhibit the writhes preferably by inhibiting the synthesis of prostaglandins are considered as peripherally acting analgesic drugs $[16,30]$. On the basis of our findings it could be recommended that AETS exhibits peripheral analgesic effect that might be mediated by inhibiting, either the response or releases of noxious mediators that leads to sensitization and activation of peripheral nociceptors. Moreover, these findings has been confirmed by our recently published research data, in which the ethyl acetate extract exhibited profound anti-inflammatory potential against prostaglandin $E_{2}$ induced paw edema test model in mice [31].

Formalin induced pain paradigm is a well recommended biphasic procedure for the determination of antinociceptive activity [32]. The first phase is for initial $5 \mathrm{~min}$ (neurogenic phase) and the second phase takes 20 to $30 \mathrm{~min}$ (inflammatory phase). AETS has significantly decreased the paw licking in both neurogenic and inflammatory phases of formalin induced paw liking test in mice. The extract caused 33.45 and $67.61 \%$ inhibition in phase I and II respectively (Table 4). It is well documented that the centrally acting drugs significantly inhibits both phases while peripherally acting drugs can only inhibits phase II. Thus the antinociceptive potential might be due to involvement of both peripheral and central path ways.

To ascertain central analgesic activity we have carried out tail immersion test. Tail immersion test is specific test for the evaluation of central analgesic activity. AETS has significantly $(* * P<0.01)$ increased the pain threshold. The extract demonstrated maximum (64 \%) antinociceptive activity at $300 \mathrm{mg} / \mathrm{kg}$, indicating the involvement of both spinal and supraspinal path ways of analgesia. The analgesic effect was compared with Tramadol $^{\mathrm{R}}$, centrally acting analgesic drug and produce similar analgesic effect like Morphine. Contrary to the achievement of significant threshold (60 min) by AETS, Tramadol ${ }^{\mathrm{R}}$ has efficiently and significantly raised the thermal pain threshold within $30 \mathrm{~min}$ as shown in Table 5. In order to assess the involvement of opioids receptors in the process, the analgesic effect was antagonized with Naloxone (opioids antagonist). Naloxone significantly reversed the antinociceptive activity of both Tramadol ${ }^{\mathrm{R}}$ and AETS, which confirmed the central analgesic activity of AETS (Table 5). In carrageenan induced paw edema

Table 5 Effect of AETS 100, 200 and 300 mg/kg in tail immersion test

\begin{tabular}{|c|c|c|c|c|c|c|}
\hline \multirow[t]{2}{*}{ Samples/standard } & \multirow[t]{2}{*}{ Dose $\mathrm{mg} / \mathrm{kg}$} & \multicolumn{5}{|c|}{ Tail withdrawing time in sec } \\
\hline & & 0 min & $30 \mathrm{~min}$ & $60 \mathrm{~min}$ & $90 \mathrm{~min}$ & $120 \mathrm{~min}$ \\
\hline Normal saline & $10 \mathrm{ml} / \mathrm{kg}$ & $3.35 \pm 0.11$ & $3.48 \pm 0.16$ & $3.22 \pm 0.032$ & $3.39 \pm 0.20$ & $3.34 \pm 0.19$ \\
\hline \multirow[t]{3}{*}{ AETS } & 100 mg/kg & $3.35 \pm 0.04^{\mathrm{n} . \mathrm{s}}$ & $3.61 \pm 1.03^{\mathrm{n} . \mathrm{s}}$ & $4.02 \pm 1.03^{*}$ & $3.96 \pm 0.4^{*}$ & $3.76 \pm 1.04 *$ \\
\hline & 200 mg/kg & $3.36 \pm 1.34^{\mathrm{n} . \mathrm{s}}$ & $4.19 \pm 1.07^{*}$ & $4.55 \pm 0.07^{* *}$ & $4.48 \pm 0.1^{* *}$ & $4.20 \pm 2.10^{* *}$ \\
\hline & 300 mg/kg & $3.37 \pm 0.4^{n . s}$ & $4.80 \pm 0.21^{*}$ & $5.36 \pm 0.11^{* *}$ & $5.30 \pm 0.12^{* *}$ & $5.03 \pm 0.10^{* *}$ \\
\hline Tramadol $^{R}$ & $30 \mathrm{mg} / \mathrm{kg}$ & $3.5 \pm 0.20^{n . s}$ & $4.99 \pm 1.33^{* *}$ & $5.69 \pm 0.02^{* *}$ & $5.49 \pm 0.06^{* *}$ & $5.39 \pm 0.05^{* *}$ \\
\hline \multicolumn{7}{|c|}{ Antinociceptive effect of AETS and Tramadol ${ }^{R}$ antagonized by Naloxone } \\
\hline AETS & $300 \mathrm{mg} / \mathrm{kg}$ & $3.37 \pm 1.05^{\mathrm{n.s}}$ & $4.10 \pm 2.10^{n . s}$ & $4.13 \pm 1.07^{\mathrm{n} . \mathrm{s}}$ & $4.20 \pm 1.05^{n . s}$ & $4.26 \pm 1.70^{\text {n.s }}$ \\
\hline Tramadol $^{R}$ & $30 \mathrm{mg} / \mathrm{kg}$ & $3.38 \pm 1.04^{n . s}$ & $3.75 \pm 2.41^{n .5}$ & $3.72 \pm 1.50^{n . s}$ & $3.75 \pm 1.02^{n . s}$ & $3.70 \pm 1.04^{n .5}$ \\
\hline
\end{tabular}

Values expressed as mean \pm SEM, The data was analyzed by ANOVA followed by Dunnett's test, $n . s$ shows statistically non significant values, ** $p<0.01$ and ${ }^{*} p<0.05$ vs. control group $(\mathrm{n}=6)$ 
Table 6 Concentration dependent anti-inflammatory effect of AETS in carrageenan induced paw edema test

\begin{tabular}{lllllll}
\hline Test sample/drug & Dose $\mathrm{mg} / \mathrm{kg}$ & $1 \mathrm{~h}$ & $2 \mathrm{~h}$ & $3 \mathrm{~h}$ & $4 \mathrm{~h}$ & $5 \mathrm{~h}$ \\
\hline Normal saline & $10 \mathrm{ml}$ & $0.220 \pm 0.011$ & $0.233 \pm 0.84$ & $0.235 \pm 1.084$ & $0.236 \pm 1.033$ & $0.236 \pm 1.02$ \\
Diclofenac sodium & 10 & $0.160 \pm 0.106$ & $0.101^{* *} \pm 1.08$ & $0.070^{* *} \pm 1.028$ & $0.081^{* *} \pm 1.05$ & $0.096^{* *} \pm 1.07$ \\
AETS & 100 & $0.205 \pm 1.084$ & $0.196 \pm 0.11$ & $0.181^{*} \pm 1.10$ & $0.195^{*} \pm 1.30$ & $0.201^{*} \pm 1.06$ \\
& 200 & $0.195 \pm 1.0764$ & $0.178 \pm 1.87$ & $0.143^{* *} \pm 0.98$ & $0.150^{* *} \pm 0.10$ & $0.158^{*} \pm 0.88$ \\
& 300 & $0.171^{*} \pm 0.79$ & $0.138^{* *} \pm 0.80$ & $0.106^{* *} \pm 1.08$ & $0.111^{* *} \pm 1.10$ & $0.118^{* *} \pm 0.11$ \\
\hline
\end{tabular}

Values are reported as mean $\pm \mathrm{SEM}, \mathrm{n}=06$. Data was analyzed by ANOVA followed by post hoc Dunnett's test. Asterisks show significant values from control. ${ }^{*} p<0.01,{ }^{* *} p<0.001$

test AETS demonstrated a concentration dependent anti-inflammatory activity at all test doses (100, 200 and $300 \mathrm{mg} / \mathrm{kg}$ ). The anti-inflammatory activity with average volume of paw edema is shown in Table 6 and the percent inhibition of paw edema of aqueous fraction is presented in Fig. 1. The edema created by carrageenan injection was inhibited by the extract in dose dependent manner. A rich literature is available which signify the role of the medicinal plants in the management of inflammation [33]. Numerous researchers have evaluated different classes of phytochemicals for anti-inflammatory activity. Flavonoids mostly exerts anti-inflammatory effect by interfering with arachidonic acid metabolism [34]. Saponins also possess profound anti-inflammatory and cytotoxic activities [35, 36]. The AETS at a doses of 100 and $200 \mathrm{mg} / \mathrm{kg}$ displayed 23 and $39 \%$ inhibition of paw edema at $3 \mathrm{~h}$ after carrageenan sub planter injection, while $300 \mathrm{mg} / \mathrm{kg}$ of AETS displayed marked anti-inflammatory activity that became significant $\left({ }^{* * P} P<0.01\right)$ at $2 \mathrm{~h}$ and remained persistent throughout the procedure, showing maximum effect of $53 \%$ at $3 \mathrm{~h}$ after carrageenan sub planter injection. Diclofenac sodium displayed comparatively more significant percent inhibition $(71 \%$,

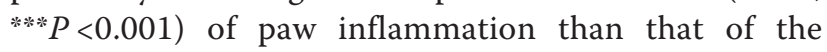
test doses of AETS of T. stocksianum (Fig. 1).

\section{Conclusion}

We concluded from the current research work that the aqueous extract of T. stocksianum (AETS) possesses marked antioxidant, analgesic and antiinflammatory potentials. AETS has shown both peripheral and central antinociceptive activity in a dose dependent manner. The extract also significantly inhibited the inflammation induced by carrageenan. All these activities might be attributed to flavonoids and saponins present in AETS. Based on our findings we recommend the plant extract for bioassay guided isolation of the secondary metabolites, to uncover the mechanism of above mentioned activities.

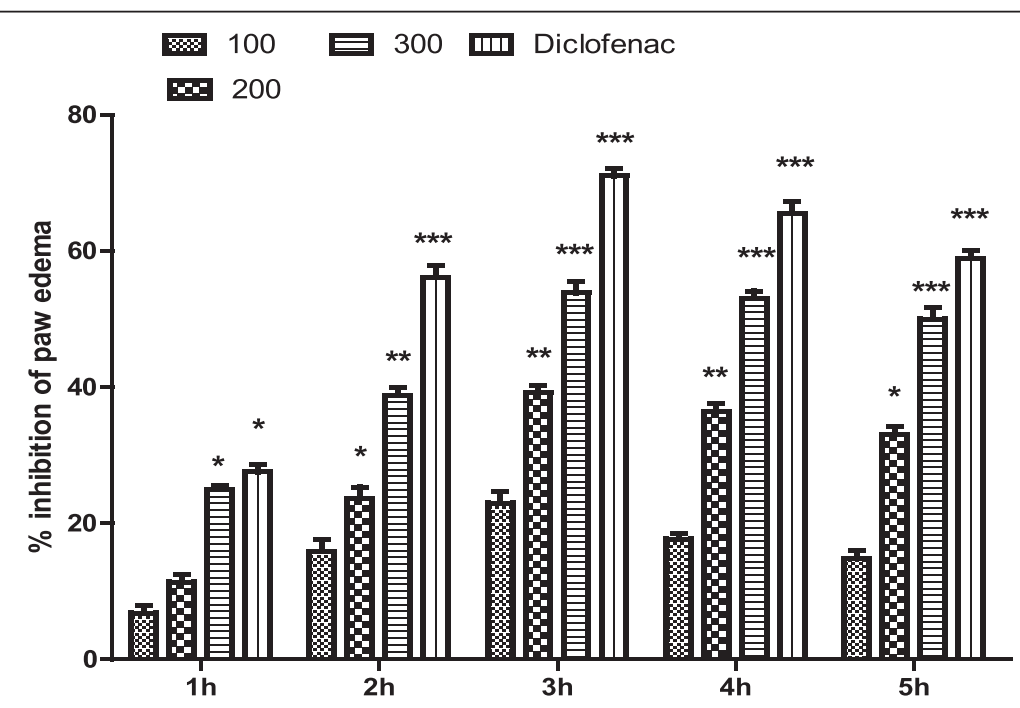

Fig. 1 Percent inhibition produced by AETS (100, 200 and $300 \mathrm{mg} / \mathrm{kg})$ of in carrageenan induced paw edema model in mice. Each percent point represents the mean \pm SEM for group of 06 mice. Data was analyzed by ANOVA followed by post hoc Dunnett's test. Asterisks show significant values from control. ${ }^{*} P<0.05,{ }^{* *} P<0.01$ and ${ }^{* * *} P<0.001$ 


\section{Competing interests}

The authors declare that they have no competing interests.

\section{Author's contributions}

SMMS performed all the experiments and manuscript drafting; SMHS did literature survey. Before submission all the authors have checked and approved the final manuscript.

\section{Authors' information}

Not applicable.

\section{Acknowledgments}

All the authors are thankful to the Professor Dr. Nisar, Department of Botany of the same University for the identification of the plant. We are also thankful to Mr. Syed Naeemudin Gillani, In-charge of Pharmacology section, Pakistan council of science and industrial research, KPK, Peshawar, Pakistan for providing access and technical assistance on Plethysmometer (used for anti-inflammatory activity determination).

\section{Author details}

'Department of Pharmacy, University of Malakand, Chakdara Dir, KPK, Pakistan. ${ }^{2}$ Department of Pharmacy, Sarhad University of Science and Information Technology, Peshawar, KPK, Pakistan.

Received: 31 May 2015 Accepted: 21 September 2015

\section{Published online: 07 October 2015}

\section{References}

1. Aynehchi Y. Pharmacognosy and medicinal plants of Iran. Tehran: Tehran University Press; 1986.

2. Hooper D, Field H, Dahlgren BE. Useful plants and drugs of Iran and Iraq vol. 9. Chicago: Field Museum of Natural History; 1937.

3. Gh A. Popular medicinal plants of Iran. Tehran: Iranian Research Institute of Medicinal Plants; 1991. p. 80.

4. Pharmacopoeia $\mathrm{H}$. Ministry of Health and Medical Education. Tehran: Food and Drug Deputy; 2002. p. 51-2.

5. Malakov P, Papanov G, Mollov N. Montanin A and B, new furanoid diterpenes of nor-clerodane type from teucrium montanum $L$. Tetrahedron Lett. 1978;19(23):2025-6.

6. Malakov PY, Papanov GY, Boneva IM. Neo-clerodane diterpenoids from teucrium montanum. Phytochemistry. 1992;31(11):4029-30.

7. Sundaresan PR, Slavoff SA, Grundel E, White KD, Mazzola E, Koblenz D, et al. Isolation and characterisation of selected germander diterpenoids from authenticated Teucrium chamaedrys and T. canadense by HPLC, HPLC-MS and NMR. Phytochem Anal. 2006;17(4):243-50.

8. Zhu Y, Li G. Studies on the diterpenoids on Teucrium quadrifarium Buch-Ham. Yao Xue Xue Bao. 1992;28(9):679-83.

9. Coll J, Tandron Y. Isolation and structure elucidation of three neo-clerodane diterpenes from Teucrium fruticans L. (LABIATAE). Phytochemistry. 2005;66(19):2298-303.

10. Ricci D, Fraternale D, Giamperi L, Bucchini A, Epifano F, Burini G, et al. Chemical composition, antimicrobial and antioxidant activity of the essential oil of Teucrium marum (Lamiaceae). J Ethnopharmacol. 2005;98(1-2):195-200.

11. Khoshnood-Mansoorkhani MJ, Moein MR, Oveisi N. Anticonvulsant activity of Teucrium polium against seizure induced by PTZ and MES in mice. Iran J Pharm Res. 2010:9(4):395-401.

12. Ahmad B, Mukarram Shah SM, Khan H, Hassan Shah SM. Enzyme inhibition activities of Teucrium royleanum. J Enzyme Inhib Med Chem. 2007;22(6):730-2.

13. Ahmad B, Mukaram Shah S, Bashir S, Begum H. Antibacterial and antifungal activities of teucrium royleanum (Labiatea). J Enzyme Inhib Med Chem. 2008;23(1):136-9

14. Shah SMM, Sadiq A, Shah SMH, Khan S. Extraction of saponins and toxicological profile of Teucrium stocksianum boiss extracts collected from District Swat, Pakistan. Biol Res. 2014;47(1):65.

15. Shah SMM, Sadiq A. Biological activities of crude saponins, methanolic extract and sub fractions of Teucrium stocksianum bioss collected from North West of Pakistan. 2014

16. Shah SMM, Ullah F, Shah SMH, Zahoor M, Sadiq A. Analysis of chemical constituents and antinociceptive potential of essential oil of Teucrium
Stocksianum bioss collected from the North West of Pakistan. BMC Complement Altern Med. 2012;12(1):244.

17. Shah SM, Sadiq A, Ullah F. Antioxidant, total phenolic contents and antinociceptive potential of Teucrium stocksianum methanolic extract in different animal models. BMC Complement Altern Med. 2014;14(1):181.

18. Khan H, Saeed M, Gilani AU, Khan MA, Dar A, Khan I. The antinociceptive activity of Polygonatum verticillatum rhizomes in pain models. J Ethnopharmacol. 2010;127(2):521-7.

19. Chou H-J, Kuo J-T, Lin E-S. Comparative antioxidant properties of water extracts from different parts of beefsteak plant (Perilla frutescens). J Food Drug Anal. 2009;17:489-96.

20. Garg VK, Khosa R. Analgesic and anti-pyretic activity of aqueous extract of Cynodon dactylon. Pharmacologyonline. 2008;3:12-8.

21. Singh S, Majumdar DK, Rehan HM. Evaluation of anti-inflammatory potential of fixed oil of Ocimum sanctum (Holybasil) and its possible mechanism of action. J Ethnopharmacol. 1996;54(1):19-26.

22. Muhammad N, Saeed M, Khan H. Antipyretic, analgesic and anti-inflammatory activity of Viola betonicifolia whole plant. BMC Complement Altern Med. 2012;12(1):59.

23. Adedapo AA, Sofidiya MO, Maphosa V, Moyo B, Masika PJ, Afolayan AJ. Anti-inflammatory and analgesic activities of the aqueous extract of Cussonia paniculata stem Bark. Rec Nat Products. 2008;2(2):46-53.

24. Afonso V, Champy R, Mitrovic D, Collin P, Lomri A. Reactive oxygen species and superoxide dismutases: role in joint diseases. Joint Bone Spine. 2007;74(4):324-9.

25. Halliwell B. Free radicals, reactive oxygen species and human disease: a critical evaluation with special reference to atherosclerosis. Br J Exp Pathol. 1989;70(6):737.

26. Firuzi O, Lacanna A, Petrucci R, Marrosu G, Saso L. Evaluation of the antioxidant activity of flavonoids by "ferric reducing antioxidant power" assay and cyclic voltammetry. Biochim Biophys Acta. 2005;1721(1):174-84.

27. Sannigrahi S, Mazumder UK, Pal D, Mishra M, Maity S. Flavonoids of Enhydra Fluctuans exhibits analgesic and anti-inflammatory activity in different animal models. Pak J Pharm Sci. 2011;24(3):369-75.

28. Collier H, Dinneen L, JOHNSON CA, Schneider C. The abdominal constriction response and its suppression by analgesic drugs in the mouse. Br J Pharmacol Chemother. 1968;32(2):295-310.

29. Hua X-Y, Yaksh TL. Pharmacology of the effects of bradykinin, serotonin, and histamine on the release of calcitonin gene-related peptide from C-fiber terminals in the rat trachea. J Neurosci. 1993;13(5):1947-53.

30. Duarte I, Nakamura M, Ferreira S. Participation of the sympathetic system in acetic acid-induced writhing in mice. Braz J Med Biol Res. 1987;21(2):341-3.

31. Shah SMM. A possible anti-inflammatory mechanism of ethyl acetate extracts of Teucrium stocksianum Bioss. BMC Complement Altern Med. 2015;15(1):299

32. Khan H, Saeed M, Khan MA, Dar A, Khan I. The antinociceptive activity of Polygonatumverticillatum rhizomes in pain models. J Ethnopharmacol. 2010;127(2):521-7.

33. Kaileh M, Berghe W, Boone E, Essawi T, Haegeman G. Screening of indigenous Palestinian medicinal plants for potential anti-inflammatory and cytotoxic activity. J Ethnopharmacol. 2007;113(3):510-6.

34. Ferrandiz M, Alcaraz M. Anti-inflammatory activity and inhibition of arachidonic acid metabolism by flavonoids. Agents Actions. 1991;32(3-4):283-8.

35. Benavente-Garcia O, Castillo J. Update on uses and properties of citrus flavonoids: new findings in anticancer, cardiovascular, and anti-inflammatory activity. J Agric Food Chem. 2008;56(15):6185-205.

36. Navarro $P$, Giner RM, Recio MC, Máñez S, Cerdá-Nicolás M, Ríos J-L. In vivo anti-inflammatory activity of saponins from Bupleurum rotundifolium. Life Sci. 2001;68(10):1199-206. 